\title{
The Distribution of Cuban Brown Anoles, Anolis sagrei (Squamata: Dactyloidae), in Mexico, with New Records and Comments on Ecological Interactions
}

Víctor Vásquez-Cruz ${ }^{1}$, Arleth Reynoso-Martínez ${ }^{1}$, Axel Fuentes-Moreno² ${ }^{2}$ and Luis Canseco-Márquez ${ }^{3}$

1PIMVS Herpetario Palancoatl, Avenida 19 número 5525, Colonia Nueva Esperanza, C.P. 94540, Córdoba, Veracruz, México (victorbiolvc@gmail.com) ${ }^{2}$ Programa de Ganadería, Colegio de Postgraduados, Campus Montecillo. Carretera México-Texcoco, km 36.5, Montecillo, Texcoco, Estado de México, México ${ }^{3}$ Departamento de Biología Evolutiva, Museo de Zoología, Facultad de Ciencias, UNAM, AP 70-399 México, D.F. 04510, México

\begin{abstract}
The Cuban Brown Anole (Anolis sagrei) is native to the Bahamas, the Cuba Archipelago, and Little Cayman, but is now among the world's most widely distributed invasive lizards. In Mexico, the species has been reported from the states of Campeche, Chiapas, Jalisco, Quintana Roo, Tabasco, Tamaulipas, Veracruz, and Yucatán. However, no complete compendium exists summarizing the locality-level distribution of $A$. sagrei in Mexico. Herein we provide an exhaustive compilation of vouchered Mexican specimens based on museum records and the literature. Supplementing this review are reports of five new localities for $A$. sagrei in Veracruz and Tabasco. We conclude with brief comments on the potential ecological effects of this species in Mexico.
\end{abstract}

$\mathrm{T}$ he Cuban Brown Anole (Anolis sagrei) is native to the Bahamas, Cuba, and Little Cayman (Powell and Henderson 2012). Widely introduced, it has become established on a number of Caribbean islands (Powell et al. 2011), Central America, including Mexico (Lee 1996; McCranie and Köhler 2015; Batista et al. 2019), the United States (Kraus 2009), Ecuador (Amador et al. 2017), Brazil (Oliveira et al. 2018), Singapore (Tan and Lim 2012), and Taiwan (Norval et al. 2002). Interestingly, Smith and Burger (1949) described a subspecies, Anolis sagrei mayensis, from Panloa Island, Campeche, Mexico, implying that Mexican populations are not necessarily exotic (Yáñez-Arenas et al. 2016). However, González-Sánchez et al. (2017), in the most recent comprehensive treatment of the herpetofauna of the Yucatán Peninsula (comprising all or part of the Mexican states of Campeche, Quintana Roo, Tabasco, and Yucatán), considered $A$. sagrei a non-native species to this region. We tentatively concur.

In Mexico, Anolis sagrei has been reported from the states of Campeche, Chiapas, Jalisco, Quintana Roo, Tabasco, Tamaulipas, Veracruz, and Yucatán (Lee 1996; ÁlvarezRomero et al. 2008; Terán-Juárez et al. 2015; ToscanoFlores and Calzada-Arciniega 2015; Venerozo-Tlazalo et al. 2017; Pazos-Nava et al. 2019). In Veracruz, populations are known from the municipalities of Los Tuxtlas (GonzálezSoriano et al. 1997), Minatitlán (Mestizo-Rivera 2006;
Zamora-Abrego et al. 2006), Alvarado (Toscano-Flores and Calzada-Arciniega 2015), Córdoba (Venerozo-Tlazalo et al. 2017), and Banderilla (MZFC 5479-1). In Tabasco, A. sagrei populations have been reported near the coast, $30 \mathrm{~km}$ north of Villahermosa (USNM 192544), and the municipalities of Cárdenas (Sánchez 2013), and Huimanguillo (Sánchez 2015). Herein we document additional populations of $A$. sagrei in both Veracruz and Tabasco and provide a comprehensive compendium of vouchered $A$. sagrei localities for Mexico.

We built a database of records of Anolis sagrei in Mexico in the Global Biodiversity Information Facility (https://www. gbif.org), VertNet (http://www.vertnet.org/index.html), and in the published literature (Table 1). We excluded some records under circumstances proposed by Soto-Huerta and Clause (2017): (1) the existing locality data were ambiguous, available only at the municipality level; (2) an irreconcilable contradiction existed between the locality's written description and global positioning system coordinates; (3) the locality referenced a place name absent from existing maps and lacked global positioning system coordinates; or (4) the location was within two kilometers of one or more other locations, in which case we generated a single point. This database includes five newly documented locations for $A$. sagrei in the states of Veracruz and Tabasco (Fig. 1), for which we deposited digital photographic vouchers at the Natural History 
Table 1. Vouchered localities for Cuban Brown Anoles (Anolis sagrei) in Mexico based on a review of museum collections and pertinent literature. $\mathrm{CM}=$ Carnegie Museum of Natural History; CNAR = Colección Nacional de Anfibios y Reptiles; ECNB = colecciones de la Escuela Nacional de Ciencias Biológicas; ECO-CH-H = Museo de Zoología, El Colegio de la Frontera Sur, Unidad Chetumal; ECO-SC-H = Colección Herpetológica del Sureste de México; IHNE-CZRHE = Instituto de Historia Natural y Ecología; KU = University of Kansas Biodiversity Institute; LACM = Natural History Museum of Los Angeles County; LSUMZ = Louisiana State University Museum of Natural Science; MCZ R = Reptile Collection, Museum of Comparative Zoology, Harvard University; MCZ = Museum of Comparative Zoology, Harvard University; MZFC = Museo de Zoología de la Facultad de Ciencias, UNAM; OMNH = Sam Noble Oklahoma Museum of Natural History; UCM = University of Colorado Museum of Natural History; UF = Florida Museum of Natural History; UIMNH = Collection of Herpetology, University of Illinois; UMMZ = Collection of Herpetology, University of Michigan; UTEP = Collection of Herpetology, University of Texas-El Paso; USNM = National Museum of Natural History, Smithsonian Institution.

\begin{tabular}{|c|c|c|}
\hline State (Municipalty) & Locality & Voucher/Reference \\
\hline Campeche (Campeche) & Campeche & UCM 18427 \\
\hline Campeche (Campeche) & Ciudad del Carmen & KU 157205 \\
\hline Campeche (Campeche) & Ciudad del Carmen & UCM 20663 \\
\hline Campeche (Carmen) & Isla Aguada & CNAR 3482 \\
\hline Campeche (Carmen) & Panlao & UIMN H4170 \\
\hline Campeche (Calakmul) & KM20, Dos Naciones, Mancolona & Colston et al. 2015 \\
\hline Campeche (—) & Los Petenes, heading to Yultan & IHNE-CZRHE 536 \\
\hline Campeche (Carmen) & Encarnación & USNM 137211 \\
\hline Chiapas (Ocozocoautla de Espinosa) & Ocozocoautla-Mal Paso, km 43 of the road & IHNE-CZRHE 1342 \\
\hline Chiapas (Tecpan) & Nueva Alianza & ECO-SC-H 91 \\
\hline Chiapas (Ocozocoautla de Espinosa) & El Cielito, $1 \mathrm{~km}$ al W & ECO-SC-H 104 \\
\hline Chiapas (Ocozocoautla de Espinosa) & El Aguajito, $1 \mathrm{~km} \mathrm{~W}$ & ECO-SC-H 40 \\
\hline Jalisco (Puerto Vallarta) & Cuale River Island & Pazos-Nava et al. 2019 \\
\hline Tabasco $(\longrightarrow)$ & $30 \mathrm{mi} \mathrm{N}$ of Villahermosa & USNM 192544 \\
\hline Tabasco (Cárdenas) & Garden of 0.5 ha of a house in a rural area & Sánchez, 2013 \\
\hline Tabasco (Huimanguillo) & Campus Tabasco, Colegio de Postgraduados & Sánchez, 2015 \\
\hline Tabasco (Jalapa & Rancho El Tiloncho) & This study \\
\hline Tabasco (Jalapa & Rancho Santa Lucia) & This study \\
\hline Tamaulipas (Altamira) & Altamira City & Terán-Juárez et al. 2015 \\
\hline Tamaulipas (Madero) & Madero City & Terán-Juárez et al. 2015 \\
\hline Veracruz (Boca del Rio) & Las Vegas colony & This study \\
\hline Veracruz (Yanga) & $2.5 \mathrm{~km} \mathrm{~W}$ of Yanga & This study \\
\hline Veracruz (Alvarado) & Los Aguacates colony & This study \\
\hline Veracruz (Córdoba) & Córdoba & Venerozo-Tlazalo et al. 2017 \\
\hline Veracruz (Banderilla) & Esquilón, between Banderillas and Jilotepec & MZFC 5479-1 \\
\hline Veracruz (Los Tuxtlas) & Catemaco & González-Soriano et al. 1997 \\
\hline Veracruz (Minatitlán) & ca. $1 \mathrm{~km} \mathrm{~N}$ of Minatitlán & Zamora-Abrego et al. 2006 \\
\hline Veracruz (Alvarado) & Mandinga & Toscano-Flores and Calzada-Arciniega 2015) \\
\hline Yucatán (San Felipe) & Near Gulf of Mexico, mouth of Rio Lagarto & UF 27737 \\
\hline Yucatán (Progreso) & Progreso, grounds of Hotel Cocoteros & OMNH 33369 \\
\hline Yucatán (Progreso) & - & OMNH 33371 \\
\hline Yucatán (Rio Lagartos) & $2 \mathrm{~km} \mathrm{S,} 5.5 \mathrm{~km} \mathrm{~W}$ Las Coloradas & ECNB 14591 \\
\hline Yucatán (Rio Lagartos) & Rio Lagartos & KU 157211 \\
\hline Yucatán (Dzilam Bravo) & Dzilam Bravo & KU 157215 \\
\hline
\end{tabular}


(continued from previous page)

\begin{tabular}{|c|c|c|}
\hline State (Municipalty) & Locality & Voucher/Reference \\
\hline Yucatán (Celestun) & Celestún Village & ECO-CH-H 1708 \\
\hline Yucatán (Celestun) & Celestun & KU 157227 \\
\hline Yucatán (Tizimín) & El Cuyo & ECNB 14600 \\
\hline Yucatán (Merida) & Merida & UCM 18424 \\
\hline Yucatán (Chichen itza) & Chichen Itza, Thompson's Cenote & UCM 28657 \\
\hline Yucatán (Tinum) & Pisté & UCM 45597 \\
\hline Yucatán (—) & Isla Pérez & MZFC28487 \\
\hline Yucatán (Ticul) & Ticul & MZFC 6192-1 \\
\hline Yucatán (Calakmul) & Xpujil & Calderón et al. 2003 \\
\hline Yucatán (Valladolid) & Valladolid & KU 298652 \\
\hline Quintana Roo (Cozumel) & Cozumel Island, E side of Punto Morena & UF 122710 \\
\hline Quintana Roo (Othón P. Blanco) & Ciudad Chetumal & CM 45279 \\
\hline Quintana Roo (Cozumel) & San Miguel, Casa Candela Room 5 & CM 55814 \\
\hline Quintana Roo (Isla Mujeres) & Isla Mujeres, $\mathrm{N}$ end & KU 70115 \\
\hline Quintana Roo (Othón P. Blanco) & Xcalak & KU 74872 \\
\hline Quintana Roo (Cozumel) & Isla Cozumel, 8 km NE San Miguel & KU 248756 \\
\hline Quintana Roo (Cozumel) & Isla Cozumel, 15 km S San Miguel & LACM 127400 \\
\hline Quintana Roo (Cozumel) & Xpalbarco & MCZ R-149562 \\
\hline Quintana Roo (Isla Mujeres) & Isla Contoy & UCM 21401 \\
\hline Quintana Roo (Solidaridad) & Solidaridad & MZFC 16577-1 \\
\hline Quintana Roo (Cancún) & Puerto Juárez & MCZ R-67410 \\
\hline Quintana Roo (Bacalar) & Lake Bacalar & LSUMZ 33349 \\
\hline Quintana Roo (Othón P. Blanco) & Calderitas & Badillo-Saldaña et al. 2016 \\
\hline Quintana Roo (Othón P. Blanco) & Banco Chinchorro & Charruau et al. 2015 \\
\hline Quintana Roo (Felipe Carrillo Puerto) & Ejido X-Hazil $S$ and annexes & ECO-CH-H 2803 \\
\hline Quintana Roo (Othón P. Blanco) & Ejido Caobas, in the village & ECO-CH-H 2585 \\
\hline Quintana Roo (Felipe Carrillo Puerto) & Petcacab Village & ECO-CH- H 2661 \\
\hline Quintana Roo (Felipe Carrillo Puerto) & Felipe Carrillo Puerto, RBSK, Petén en Playón & ECO-CH- H 1811 \\
\hline Quintana Roo (Othón P. Blanco) & Chetumal center & ECO-CH-H 1263 \\
\hline Quintana Roo (Felipe Carrillo Puerto) & Vigía Chico & ECO-CH-H 0022 \\
\hline Quintana Roo (Isla Mujeres) & Isla Cayo Norte Mayor & MZFC 28473 \\
\hline Quintana Roo (Isla Mujeres) & Isla Cayo & ECO-CH-H2794 \\
\hline Quintana Roo (Benito Juárez) & Benito Juárez Zona Centro & CNAR-4068 \\
\hline Quintana Roo (Puerto Morelos) & Puerto Morelos & CNAR-4104 \\
\hline Quintana Roo (Felipe Carrillo Puerto) & Bahia De La Ascención & UMMZ 78584 \\
\hline Quintana Roo (Cozumel) & Near San Miguel, along beach & UTEP-H-7488 \\
\hline Quintana Roo (Benito Juárez) & \multicolumn{2}{|c|}{3 mi E Esmeralda, 0.25 mi S Lake Chichankanab LACM-114031 } \\
\hline
\end{tabular}

Museum of Los Angeles County (LACM PC). We identified A. sagrei based on three diagnostic characters: laterally compressed tail, orange to red dewlap with a yellow margin, and enlarged post-anal scales (Köhler 2008).

Although Pazos-Nava et al. (2019) recently provided a database of Anolis sagrei localities in Mexico, they overlooked some records available on the VertNet platform and other records reported in the literature (e.g., Terán-Juárez et al. 2015). Our map and list include those missing records, and we also distilled the records to individual localities, making it easier to enumerate and visualize the site-specific Mexican distribution of the species. Based on our review, Mexican popu- 


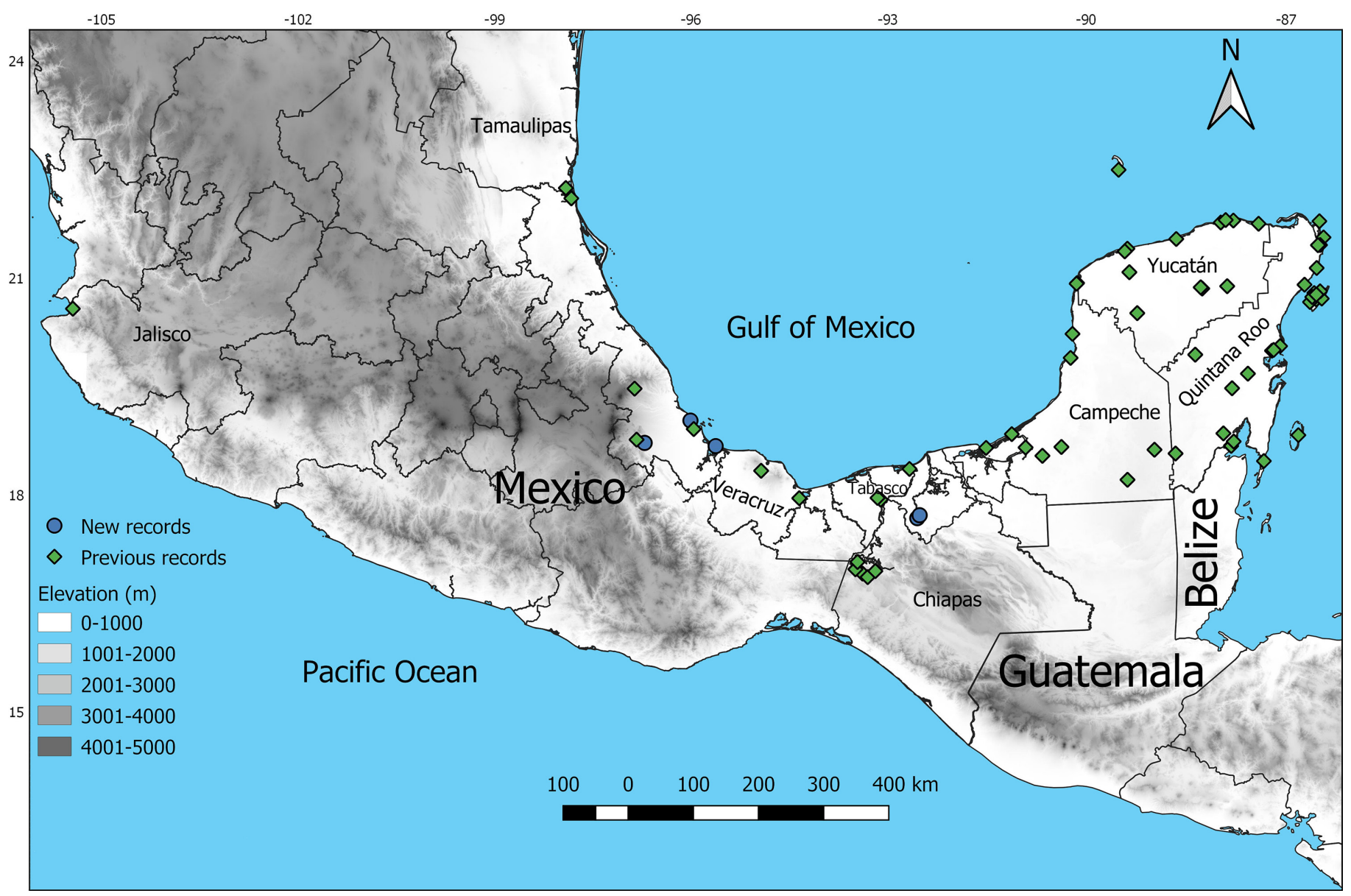

Fig. 1. Records of Cuban Brown Anoles (Anolis sagrei) in Mexico.

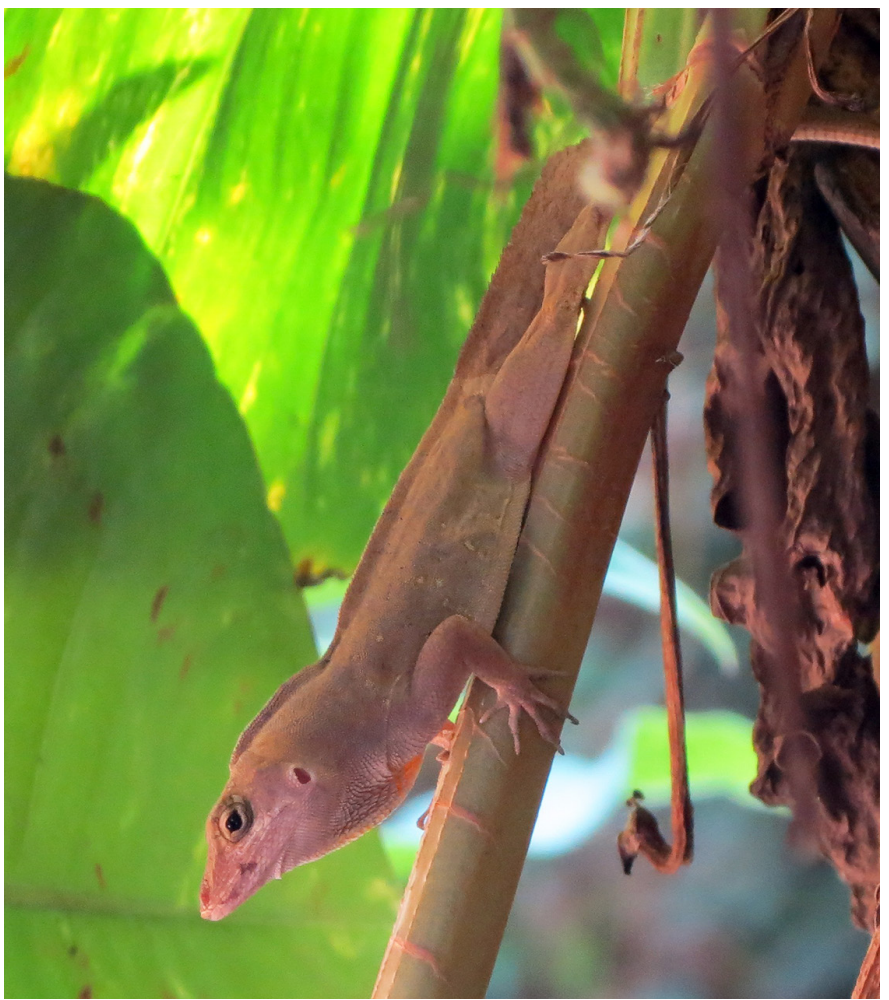

Fig. 2. An adult male Cuban Brown Anole (Anolis sagrei) from Alvarado, Veracruz (LACM PC 2469). Photograph by Axel Fuentes-Moreno. lations have been reported in 69 localities in 36 municipalities in eight states (Tables 1 and 2, Fig. 1), including five new localities based on our own recent fieldwork.

At around 0930 h on 2 January 2011, we observed several Anolis sagrei (Fig. 2) in a small $50-\mathrm{m}^{2}$ private garden in an urbanized area of Colonia los Aguacates in Alvarado, Municipality of Alvarado, Veracruz $\left(18^{\circ} 46^{\prime} 38.9^{\prime \prime} \mathrm{N}\right.$, 95\%46'08.4"W; WGS 84; elev. $30 \mathrm{~m}$ asl). On 2 October 2019, we re-surveyed the population in this same garden, recording four adults (a male and three females) and five young. We found the lizards among ornamental plants, on

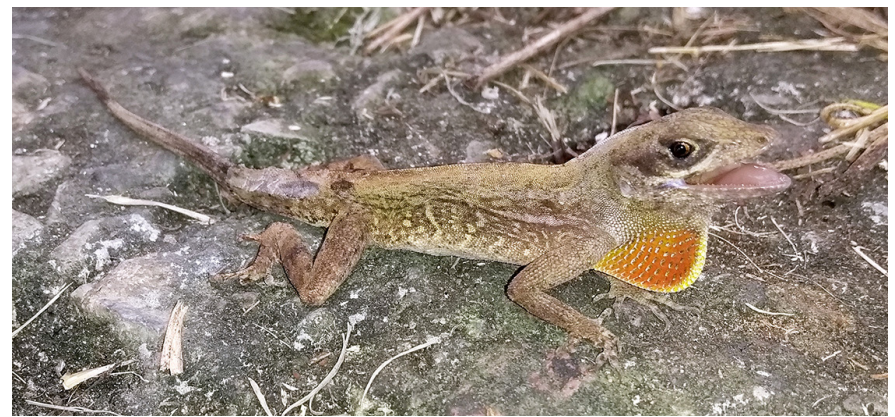

Fig. 3. An adult male Cuban Brown Anole (Anolis sagrei) from Yanga, Veracruz (LACM PC 2466). Photograph by Víctor Vásquez-Cruz. 


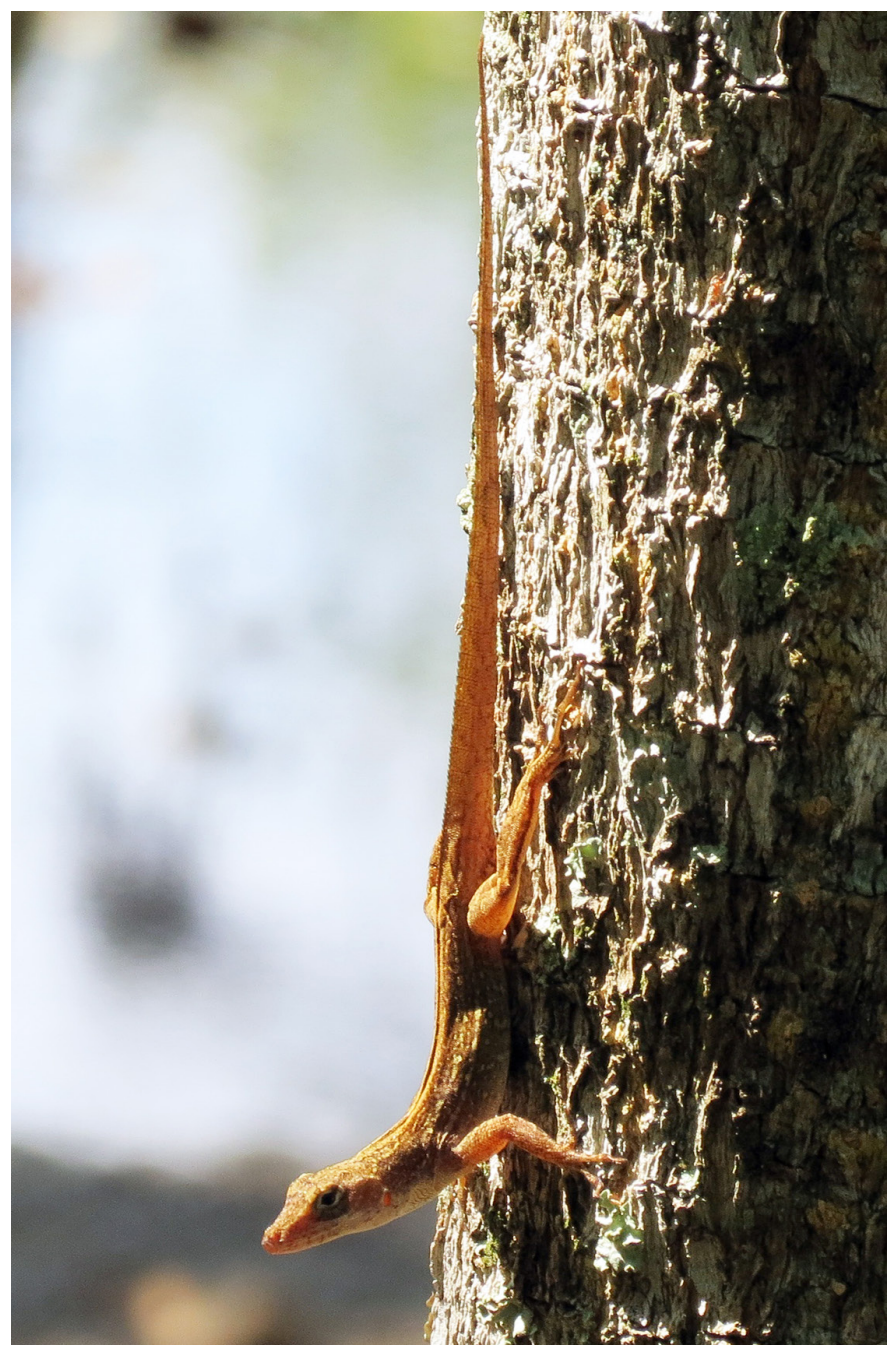

Fig. 4. An adult male Cuban Brown Anole (Anolis sagrei) from Rancho el Tiloncho, Tabasco (LACM PC 2467). Photograph by Luis CansecoMárquez.

dead plant matter, on the ground, and on the walls of the garden. We also have since observed $A$. sagrei in other gardens in the city, possibly indicating multiple independent introductions. The Colonia los Aguacates record is $42 \mathrm{~km}$ SE of the nearest previously known locality in the town of Mandinga, Municipality of Alvarado (Toscano-Flores and Calzada-Arciniega 2015).

At 1516 h on 23 May 2017, we observed many Cuban Brown Anoles in and around a greenhouse in an industrial area on the outskirts of the town of Yanga, Municipality of Yanga, Veracruz (1850'10.78"N, 96²8'25.27"W; WGS 84; elev. $540 \mathrm{~m}$ asl). We recorded seven males, nine females, and 10 juveniles (Fig. 3). The lizards were thermoregulating on the plastic greenhouse cover, on nearby rocks and tree trunks, and moving about among the Anthurium sp. plants in the greenhouse. This record is the second from west-central Veracruz and is $13.4 \mathrm{~km} \mathrm{SE}$ of the nearest previously known locality in the city of Córdoba, Municipality of Córdoba (Venerozo-Tlazalo et al. 2017).

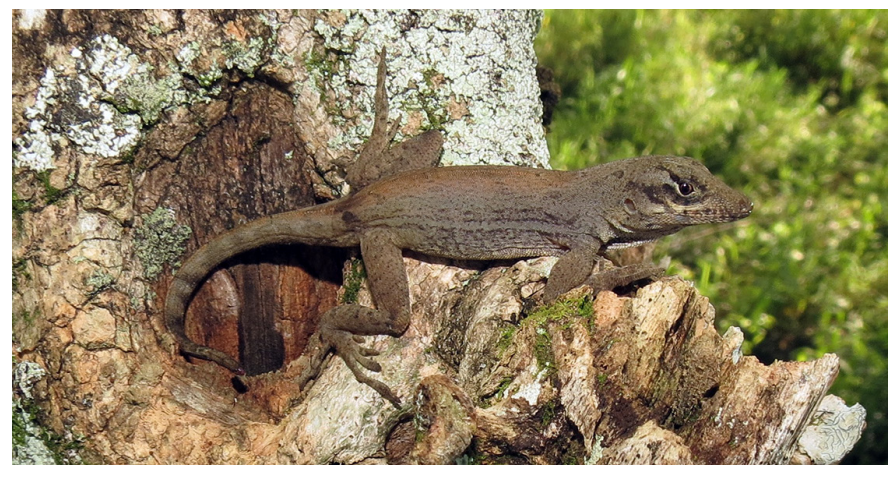

Fig. 5. An adult male Cuban Brown Anole (Anolis sagrei) from Rancho Santa Lucia, Tabasco (LACM PC 2468). Photograph by Luis Canseco-Márquez.

At around $1600 \mathrm{~h}$ on 14 December 2018, we observed a male Anolis sagrei inside a house in the Las Vegas Colony $\left(19^{\circ} 08^{\prime} 18.6^{\prime \prime N}, 96^{\circ} 07^{\prime} 52.7^{\prime \prime W}\right.$; WGS 84; elev. $8 \mathrm{~m}$ asl) in the city of Boca del Río, Municipality of Boca del Río, Veracruz. Subsequently, on 18 August 2019, we observed a juvenile $A$. sagrei in the yard of the same house, and on 4 October 2019 we encountered two $A$. sagrei in the yard, an adult male thermoregulating on a fence (Fig. 4) and a juvenile eating a spider (Lycosidae). This record is $13 \mathrm{~km} \mathrm{~N}$ of the nearest previously known locality in the town of Mandinga, Municipality of Alvarado (Toscano-Flores and Calzada-Arciniega 2015).

At around 1000 h on 3 November 2017, we observed an adult $A$. sagrei thermoregulating at the base of a stump (Fig. 5) at Rancho Santa Lucia, Municipality of Jalapa, Tabasco (1744'39.0"N, 9249'46.0"W; WGS 84; elev. 14 $\mathrm{m}$ asl). Subsequently, at around $1500 \mathrm{~h}$, we observed an adult male (Fig. 6) at Rancho El Tiloncho, Municipality of Jalapa, Tabasco (17² $42^{\prime} 19.0^{\prime \prime} \mathrm{N}, 92^{\circ} 51^{\prime} 52.0 " W ;$ WGS 84; elev. 14 $\mathrm{m}$ asl). We observed no other lizards at these sites, and both localities are characterized by a high degree of disturbance with areas destined for palm cultivation. These records are the southernmost in Tabasco. Respectively, they are 64 and $62 \mathrm{~km} \mathrm{SE}$ of the nearest previously known locality in the Municipality of Huimanguillo (Sánchez 2015).

Several types of ecological interaction have been reported between introduced $A$. sagrei and native species, including commensalism (Delaney et al. 2014a), competition (Delaney et al. 2014b), predator-prey (Simpson et al. 2019), and interspecific mating (Thawley et al. 2019). In the Yanga locality of Veracruz, we observed several Rose-bellied Lizards (Sceloporus variabilis), a species native to Mexico, and we speculate that the introduced $A$. sagrei at this site could act both as a direct predator and competitor to $S$. variabilis, similar to reports of agonistic interactions with Silky Anoles (Anolis sericeus) and Teapen Rose-bellied Lizards (Sceloporus teapensis) elsewhere in Mexico (Schüttler and Karez 2008; Yánez-Arenas et al. 2016). The potential colonization and spread of $A$. sagre $i$ in this area could also lead to negative interactions with nearby populations of Greater Scaly Anoles (A. tropidonotus) and A. sericeus, 


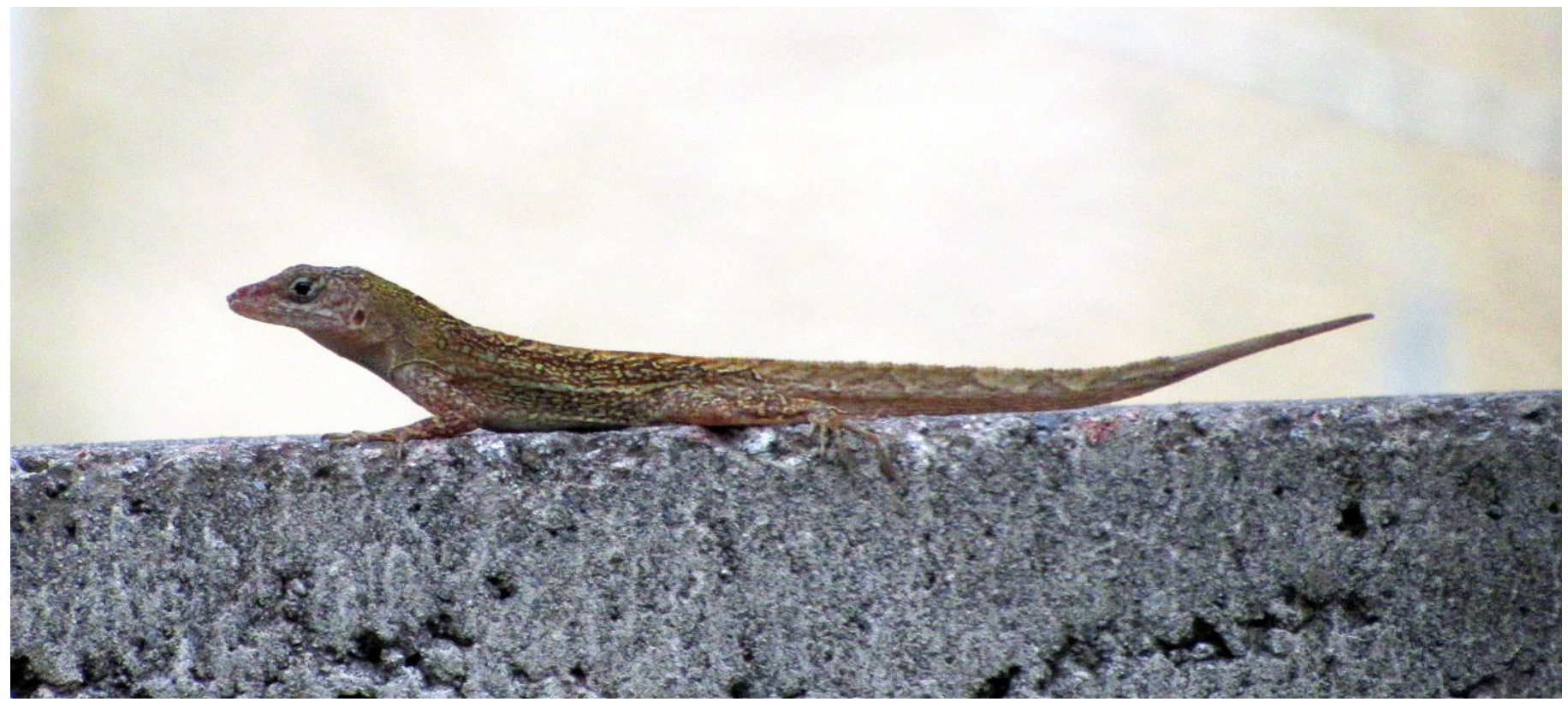

Fig. 6. An adult male Cuban Brown Anole (Anolis sagrei) from Boca del Rio, Veracruz (LACM PC 2471). Photograph by Axel Fuentes-Moreno.

Table 2. Number of municipalities and localities inhabited by Anolis sagrei in Mexico.

\begin{tabular}{lcc} 
State & Municipalities & Localities \\
\hline Campeche & 3 & 7 \\
\hline Chiapas & 2 & 5 \\
\hline Jalisco & 1 & 1 \\
\hline Quintana Roo & 8 & 27 \\
\hline Tabasco & 3 & 5 \\
\hline Tamaulipas & 2 & 2 \\
\hline Veracruz & 7 & 8 \\
\hline Yucatán & 10 & 15
\end{tabular}

which we documented in patches of vegetation within $2 \mathrm{~km}$ of the current $A$. sagrei population. Such interactions could even lead to eventual extirpation of native lizards. Notably, Anolis sericeus was previously found in the urban garden where we first documented A. sagrei in the town of Alvarado, Veracruz, but we have observed none following the colonization of this garden by $A$. sagrei. The ecological effects of the spread of A. sagrei may not, however, be entirely deleterious to native herpetofauna. For instance, we documented an A. sagrei being consumed by the native Atlantic Central American Milksnake (Lampropeltis polyzona) (V. Vásquez-Cruz, unpubl. data) at the Yanga locality.

The largest number of Anolis sagrei records in Mexico occurs in the states of Campeche, Quintana Roo, and Yucatan ( $70 \%$ of nationwide records; Table 2 ), and in the last 20 years the species has spread across the Gulf of Mexico into the states of Tabasco and Veracruz, mostly in urban areas. We identify two phenomena involved in this spread: (1) incidental introduction of $A$. sagrei via product importation or other humanmediated pathways; and (2) progressive natural colonization radiating outward from single introduction points, for example the records in Boca del Rio, Mandinga, and Alvarado in Veracruz and Rancho El Tiloncio and Rancho Santa Lucia in Tabasco. Studying the geographical origins and population status of $A$. sagrei in these locations is necessary to evaluate the speed of colonization and its impact on the native Mexican species.

\section{Acknowledgments}

We thank Adam G. Clause for valuable suggestions that improved the manuscript. We are grateful to Neftali Camacho at the Natural History Museum of Los Angeles County for cataloging our digital photographic vouchers.

\section{Literature Cited}

Álvarez-Romero, J.G., R.A. Medellín, A. Oliveras de Ita, H. Gómez de Silva, and O. Sánchez. 2008. Animales exóticos en México: una amenaza para la biodiversidad. Comisión Nacional para el Conocimiento y Uso de la Biodiversidad, Instituto de Ecología, UNAM, Secretaría de Medio Ambiente y Recursos Naturales, México, D.F.

Amador, L., F. Ayala-Varela, A.E. Nárvaez, K. Cruz, and O. Torres-Carvajal. 2017. First record of the invasive Brown Anole, Anolis sagrei Duméril \& Bibron, 1837 (Squamata: Iguanidae: Dactyloinae), in South America. Check List 13: 2083.

Badillo-Saldaña, L.M., C.I. Beteta-Hernández, A. Ramírez-Bautista, J.D. LaraTufiño, and R. Pineda-López. 2016. First records of nocturnal activity in two diurnal anole species (Squamata: Dactyloidae) from Mexico. Mesoamerican Herpetology 3: 715-718.

Batista, A., M. Ponce, O. Garces, E. Lassiter, and M. Miranda. 2019. Silent pirates: Anolis sagrei Dumeril \& Bibron, 1837 (Squamata, Dactyloidae) taking over Panama City, Panama. Check List 15: 455-459.

Calderon, R., J.R. Cedeño-Vázquez, and C. Pozo. 2003. New distributional records for amphibians and reptiles from Campeche, Mexico. Herpetological Review 
34: 269-272.

Charruau, P., A.H. Díaz de la Vega Pérez, and F.R. Méndez de la Cruz. 2015. Reptiles of Banco Chinchorro: Updated list, life history data, and conservation [Quintana Roo, Mexico]. Southwestern Naturalist 60: 299-312.

Colston, T.J., J.A.L. Barão-Nóbrega, R. Manders, A. Lett, J. Wilmott, G. Cameron, S. Hunter, A. Radage, E. Littlefair, R.J. Williams, A. Lopez Cen, and K. Slater. 2015. Amphibians and reptiles of the Calakmul Biosphere Reserve, México, with new records. Check List 11: 1759

Delaney, D.M., C.D. Cates, and D.A. Warner. 2014a. Anolis sagrei (Brown Anole). Gopherus polyphemus burrow commensalism. Herpetological Review 45: 694.

Delaney, D.M., C.D. Cates, A.M. Buckelew, D.M. Delaney, A.M. Durso, S.S. French, A.M. Reedy, and D.A. Warner. 2014b. Anolis sagrei (Brown Anole). Prey stealing behavior. Herpetological Review 45: 324-325.

González-Sánchez, V.H., J.D. Johnson, E. García-Padilla, V. Mata-Silva, D.L. DeSantis, and L.D. Wilson. 2017. The herpetofauna of the Mexican Yucatan Peninsula: Composition, distribution, and conservation status. Mesoamerican Herpetology 4: 264-380.

González Soriano E., R. Dirzo, and C. Vogt (eds.). 1997. Historia Natural de Los Tuxtlas. UNAM, Instituto de Biología, México, D.F.

Köhler, G. 2008. Reptiles of Central America. 2nd edition. Herpeton Verlag, Offenbach, Germany.

Kraus, F. 2009. Alien Reptiles and Amphibians: A Scientific Compendium and Analysis. Invading Nature-Springer Series in Invasion Ecology, Volume 4. Springer Verlag, Dordrecht, The Netherlands.

Lee, J.C. 1996. The Amphibians and Reptiles of the Yucatán Peninsula. Comstock Publishing Associates, Cornell University Press, Ithaca, New York.

McCranie, J.R. and G. Köhler. 2015. The anoles (Reptilia: Squamata: Dactyloidae: Anolis: Norops) of Honduras. Systematics, distribution, and conservation. Bulletin of the Museum of Comparative Zoology, Special Publication Series 1: $1-292$.

Mestizo-Rivera, L.R. 2006. La Herpetofauna del Pantano Santa Alejandrina, Minatitlán, Veracruz, México. Unpublished Licenciatura thesis. Universidad Veracruzana, Facultad de Biología, Xalapa, Veracruz, Mexico.

Norval, G., J.J. Mao, H.P. Chu, and L.C. Chen. 2002. A new record of an introduced species, the Brown Anole (Anolis sagrei) (Duméril \& Bibron, 1837), in Taiwan. Zoological Studies 41: 332-336.

Oliveira, J.C.F., T. Macrial de Castro, D. Vrcibradic, M. Campos Drago, and I. Prates. 2018. A second Caribbean anole lizard species introduced to Brazil. Herpetology Notes 11: 761-764.

Pazos-Nava, F.N., R.I. Álvaro-Montejo, F.G. Cupul-Magaña, R. García de QuevedoMachain, U.S. Flores-Guerrero, J.A. Velasco, and A.H. Escobedo-Galván. 2019. First verified record of Anolis sagrei Cocteau in Duméril and Bibron, 1837 from the central Pacific coast of Mexico. BioInvasions Records 8: 568-574.

Powell, R. and R.W. Henderson (eds.). 2012. Island lists of West Indian amphibians and reptiles. Bulletin of the Florida Museum of Natural History 51: 85-166.
Powell, R., R.W. Henderson, M.C. Farmer, M. Breuil, A.C. Echternacht, G. van Buurt, C.M. Romagosa, and G. Perry. 2011. Introduced amphibians and reptiles in the Greater Caribbean: Patterns and conservation implications, pp. 63-143. In: A. Hailey, B.S. Wilson, and J.A. Horrocks (eds.), Conservation of Caribbean Island Herpetofaunas. Volume 1: Conservation Biology and the Wider Caribbean. Brill, Leiden, The Netherlands.

Sánchez, S. 2013. Depredación de una lagartija anolis (Norops sagrei) por un tecolote bajeño (Glaucidium brasilianum) en México. Zeledonia 17: 68-71.

Sánchez, S. 2015. Depredación de Anolis sagrei por Dives dives en México. Boletín de la Asociación Herpetológica Española. 26(1): 16-18.

Schüttler, E. and C. Karez. 2008. Especies exóticas invasoras en las Reservas de Biosfera de América Latina y el Caribe. Un informe técnico para fomentar el intercambio de 129 experiencias entre las Reservas de Biosfera y promover el manejo efectivo de las invasiones biológicas. Oficina Regional de Ciencia de la UNESCO para América Latina y el Caribe, Montevideo, Uruguay.

Simpson, S.E., S.T. Giery, J.T. Stroud, and C.J. Thawley. 2019. Anolis sagrei (Brown Anole) Predation. Herpetological Review 50: 362-363.

Smith, H.M. and W.L. Burger. 1949. A new subspecies of Anolis sagrei from the Atlantic coast of tropical America. Anales del Instituto de Biologia 10: 407-410.

Soto-Huerta, K.A. and A.G. Clause. 2017. Distribution and range extension of the Elegant Coralsnake, Micrurus elegans. The Southwestern Naturalist 62: 303-308.

Tan, H.H. and K.K.P. Lim. 2012. Recent introduction of the Brown Anole Norops sagrei (Reptilia: Squamata: Dactyloidae) to Singapore. Nature in Singapore 5: 359-362.

Terán-Juárez, S.A., E. García-Padilla, F.E. Leyto-Delgado, and L.J. García-Morales. 2015. New records and distributional range extensions for amphibians and reptiles from Tamaulipas, Mexico. Mesoamerican Herpetology 2: 208-214.

Thawley, C.J. 2019. Anolis cristatellus (Puerto Rican Crested Anole) and Anolis sagrei (Brown Anole). Interspecific mating. Herpetological Review 50: 362.

Toscano-Flores, C. and R.A. Calzada-Arciniega. 2015. Geographic distribution: Anolis sagrei (Brown Anole). Herpetological Review 46: 215.

Venerozo-Tlazalo, D.G., R. Serna-Lagunes, and V. Vásquez-Cruz. 2017. Norops sagrei (Duméril \& Bibron, 1837). Mexico, Veracruz. Mesoamerican Herpetology 4: $197-198$.

Yáñez-Arenas, C., L. Díaz-Gamboa, A. Rodríguez-Pérez, A. Salmerón-Flores, C. Patrón-Rivero, K. López-Reyes, E. Rodríguez-Silva, K. Rodríguez-Medina, A. Buenfil-Ávila, and Z. Naviat-Uc. 2016. Análisis de riesgo de reptiles con potencial invasor en México. Informe final entregado a la CONABIO y al PNUD en el marco del proyecto GEF 0097333 "Aumentar las Capacidades Nacionales para el Manejo de las Especies Exóticas Invasoras (EEI) a través de la Implementación de la Estrategia Nacional de EEI”. Unidad Académica de Yucatán - UNAM, México, D.F.

Zamora-Abrego, J.G., U.O. García-Vázquez, A. Nieto-Montes de Oca, and L. Canseco-Márquez. 2006. Geographic distribution: Anolis sagrei (Brown Anole). Herpetological Review 37: 493. 